\title{
Passively transferred myasthenia gravis: protection of mouse endplates by Fab fragments from human myasthenic IgG
}

\author{
K V TOYKA, ${ }^{*}$ B LÖWENADLER, $\dagger$ K HEININGER, $\ddagger$ U A BESINGER, \\ K L BIRNBERGER, $\S$ A FATEH-MOGHADAM, $\ddagger$ AND E HEILBRONN $\dagger$
}

From the Departments of Neurology, University of Düsseldorf* and Technical University of Munich $\$$, W Germany; the Department of Neurochemistry and Neurotoxicology, University of Stockholm, Swedent, and the Department of Clinical Chemistry Grosshadern, University of Munich, W Germany*

SUMMARY Using the mouse passive transfer model, the effects of purified human myasthenic immunoglobulin $\mathrm{G}$ and of the monovalent Fab fragment on neuromuscular junctions were investigated. Treatment with IgG markedly reduced amplitudes of miniature endplate potentials. When Fab fragments were transferred alone or with subsequent addition of IgG no neuromuscular transmission block was induced. Myasthentic IgG and Fab were specifically demonstrated at the neuromuscular junctions by immunohistochemistry. On electronmicroscopy endplate structure was normal in transfer experiments using IgG for up to 30 days. It is suggested that Fab fragments bind to acetylcholine receptors without affecting transmission and protect them from the attack of complete IgG antibodies.

Circulating antibodies (AB) to the nicotinic acetylcholine receptor (AChR) at the neuromuscular junction are probably the main cause of the transmission defect in myasthenia gravis (MG) (for review see Lennon, ${ }^{1}$ Heilbronn and Stalberg, ${ }^{2}$ Drachman. ${ }^{3}$ It has been shown that on passive transfer of human myasthenic immunoglobulins or IgG to recipient mice typical features of MG can be reproduced: (1) reduced amplitudes of miniature endplate potentials (MEPP) and endplate potentials (EPP) (2) a decrease in the number of AChR measured by $\alpha$-bungarotoxin ( $\alpha$-Butx) binding and (3) a decremental response and clinical weakness in some animals. ${ }^{4-6}$ Accelerated degradation of membrane bound AChR has been observed in mice treated identically. ${ }^{7}$

There is evidence from studies using muscle cell cultures that native IgG antibodies or bivalent $\left(F\left(a b^{\prime}\right)_{2}\right.$ fragments are needed to induce accelerated degradation of AChR but Fab fragments are inactive. ${ }^{8}$ In this study we investigated

Address for reprint requests: Prof Klaus V Toyka, Neurologische Universitatsklinik, Moorenstrasse 5, D-4000 Düsseldorf, W Germany.

Accepted 1 May 1980 the effects of Fab fragments and those of IgG from myasthenic sera on neuromuscular junctions in vivo using the mouse transfer model. It will be demonstrated that Fab fragments (1) bind to AChR but do not reproduce the myasthenic transmission defect, and (2) completely inhibit the effect of IgG on MEPP amplitudes when transferred simultaneously.

\section{Material and methods}

Patients Serum was obtained from three patients with myasthenia gravis (MG) as established by clinical signs, abnormal EMG, positive Tensilon test and antibodies to AChR (immunoprecipitation assay. ${ }^{10}$ Serum from a non-myasthenic patient and normal IgG (AB Kabi, Sweden) served as controls. Preparation of serum fractions (a) Purified IgG was isolated from the MG serum by separation on exchange chromatography using a column packed with DEAE-Sephacel (Pharmacia) $(0.05 \mathrm{M}$ phosphate buffer, $\mathrm{pH} 8 \cdot 0$ ). ${ }^{11}$ The eluates were concentrated and checked for purity on standard agar gel immunoelectrophoresis using goat anti-human whole serum (Behringwerke). The quantitative IgG concentration was measured by radial immunodiffusion (Behringwerke).

(b) In the individual control serum a crude immuno- 
globulin fraction was obtained by sterile ammonium sulphate precipitation at $33 \%$ saturation as described previously. $^{5}$

(c) The preparation of Fab fragments was carried out according to a procedure described by Porter ${ }^{12}$ with some modifications: IgG $(0.6 \mathrm{~g})$ was dissolved in $40 \mathrm{ml}$ buffer $(0.1 \mathrm{M}$ sodium phosphate, $\mathrm{pH} 7 \cdot 0$, $0.01 \mathrm{M}$ cysteine, $0.002 \mathrm{M}$ sodium-EDTA) and incubated with $6 \mathrm{mg}$ mercuripapain (Serva) at $37^{\circ} \mathrm{C}$ for 16 hours. The solution was then dialysed against distilled water to inactivate the enzyme. For chromatography on DEAE-Sephadex A 50 (Pharmacia) the digest was dialysed with starting buffer $(0.05 \mathrm{M}$ TRIS-HC1, pH 8). Column dimensions were $5 \times 35$ $\mathrm{cm}$, the flow rate was $30 \mathrm{ml} /$ hour. A linear gradient was applied with a LKB Gradient Mixer ranging from $005 \mathrm{M}$ to $0.5 \mathrm{M}$ TRIS-HC1, pH 8 , starting at 200 ml elution volume. The IgG digest was fractionated into four peaks which were found to be pure Fab (I), Fab plus Fc (II and III), and pure Fc (IV) by standard immunoelectrophoresis. After pooling, the Fab fraction was concentrated and again assessed for purity. No papain was present in the final Fab solution as demonstrated by an optical test originally described for chymotrypsin. ${ }^{13}$ Antiacetylcholine receptor antibody activity of the Fab fragments was measured by an immunoprecipitation assay $^{10}$ with the modification that the receptor-Fabcomplexes were precipitated with anti-human Fabserum (Behringwerke).

Injection of experimental animals $\mathrm{BDF}_{1}$-mice. Ten female $B 6 D 2 F_{1} / J$ mice (Jackson Laboratories, Maine, USA) were injected daily with Ig fractions fo 7 to 10 days and immunosuppressed with cyclophosphamide $(300 \mathrm{mg} / \mathrm{kg})$. To ensure sterility the purified IgG fraction was passed through a filter assembly $(0.45 \mu \mathrm{m}$ pore size, Sartorius) before injection.

Two groups of C57 mice (four animals in each group) were given daily ip injections of human myasthenic IgG and human control IgG respectively. Each dose contained about $10-12 \mathrm{mg}$ IgG. The resulting mouse-serum concentration of human IgG as measured by Tripartigen ${ }^{(R)}$ (Behringwerke) ranged from 500 to $1000 \mathrm{mg} / 100 \mathrm{ml}$. Mice receiving treatment for more than three days were immunosuppressed by a single injection of cyclophosphamide $(100 \mathrm{mg} / \mathrm{kg})$. Two mice from each group were killed and studied after three and 30 days of treatment.

Testing of neuromuscular transmission At the end of the experimental period eight mice were anaesthetised and the left hemidiaphragm was removed, transferred to a bath containing modified Liley's solution gassed with $95 \% \mathrm{O}$, and $5 \% \mathrm{CO}$, and kept at $31^{\circ} \mathrm{C}$. Intracellular recordings of MEPP were carried out by standard microelectrode techniques as described previously. ${ }^{6}$ In up to 24 muscle fibres 15-20 MEPP were recorded per fibre, the mean amplitudes per fibre calculated, and these values used to calculate the grand mean for all fibres in each diaphragm.
IMMUNOHISTOCHEMISTRY

Preparation of protein $A$ conjugated horseradish peroxidase (prot $A-H R P O)$

Protein A (Pharmacia, Sweden) was conjugated to horseradish peroxidase (type IV Sigma Chemical Co. USA) according to the method of Nakane and Kawoi. ${ }^{14}$ The conjugate was separated from unreacted components of gelfiltration on AcA44 ultrogel (LKB), as described by Engel et $a l,,^{15}$ and concentrated to $1.0 \mathrm{mg} / \mathrm{ml}$ by ultrafiltration. The conjugate solution was divided into small aliquots containing $10 \mathrm{mg} \mathrm{BSA} / \mathrm{ml}$ and stored at $-20^{\circ} \mathrm{C}$ until used. In order to determine the concentration of the conjugate which gave the best specific staining with the lowest background, the conjugate was diluted stepwise with $0.15 \mathrm{M} \mathrm{NaCl}$ in $0.1 \mathrm{M}$ phosphate buffer pH $7 \cdot 2$ (PBS) to five different concentrations $(200,100,50,25$ and $12 \cdot 5 \mu \mathrm{g} / \mathrm{ml}$. These dilutions were separately incubated with $10 \mu \mathrm{m}$ thick skeletal muscle cryosections from a rabbit with experimental autoimmune myasthenia gravis. The rabbit was earlier shown to have acetylcholine receptor antibodies bound to its motor endplates. After staining for peroxidase activity with Karnovsky's diaminobenzidine medium ${ }^{16}$ the sections were studied under light microscopy.

A conjugate concentration of $25 \mu \mathrm{g} / \mathrm{ml}$ was chosen for the further experiments since this gave low background stain with a still substantial endplate stain. Anti-human Fab antibody Rabbit anti-human Fab serum was purchased from Behringwerke. The IgG fraction was separated from serum by ammonium sulphate precipitation ${ }^{17}$ and kept at $+4{ }^{\circ} \mathrm{C}$ after lyophilisation. Before use the lyophilised powder was dissolved in PBS to a protein concentration of $1 \mathrm{mg} / \mathrm{ml}$. Three different dilutions (200, 100 and $50 \mu \mathrm{g} / \mathrm{ml}$ ) were used in the experiments.

Light microscopic localisation of $\mathrm{IgG}$ and Fab at motor endplates Mice were killed by decapitation. The left and right tibialis anterior were excised and frozen by immersion in freon chilled in liquid nitrogen. $10 \mu \mathrm{m}$ thick longitudinal cryosections of the muscles were cut on a microtome. After fixation for $15 \mathrm{~min}$ in acetone the sections were rinsed for $30 \mathrm{~min}$ at room temperature in two changes of PBS. For the localisation of $\mathrm{IgG}$, sections were incubated with Prot A-HRPO $(25 \mu / \mathrm{ml})$ for $30 \mathrm{~min}$ at room temperature, followed by washing $2 \times 15 \mathrm{~min}$ in PBS. Staining for peroxidase activity was performed with $\mathrm{H}_{3} \mathrm{O}_{2}$ and diaminobenzidine. The sections were finally rinsed $2 \times 15 \mathrm{~min}$ in $50 \mathrm{mM}$ Tris- $\mathrm{HCl}$, dehydrated in graded series of alcohol, cleared in xylol and mounted under cover glass. In the case of Fab localisation sections were first incubated with anti-human Fab 200$50 \mu \mathrm{g} / \mathrm{ml}$ ) followed by a $30 \mathrm{~min}$ rinse in PBS, and then processed as above.

Electron microscopic localisation of $1 g G$ at motor endplates Thin strips of mouse diaphragm muscle were processed for electron microscopic localisation of IgG by the method of Engel et al.15 After postfixation in $\mathrm{OsO}_{4}$ and dehydration in alcohol the 
muscle strips were embedded in Epon 812 with orientation for longitudinal sectioning. $1.5 \mu \mathrm{m}$ semithin sections were cut on an LKB ultrotome and studied under light microscope for peroxidase stain. When endplates were found in a section consecutive ultra-thin sections were cut for electron microscopy. A Philips 201EM was used.

Specificity controls In order to establish specficity of the system, control sections were either preincubated with unlabelled protein $A$ or $\mathrm{H}_{2} \mathrm{O}_{2}$ was omitted from the staining medium.

\section{Results}

\section{Passive transfer of $\operatorname{IgG}$}

The MEPP-amplitude in the control diaphragm was $0.70 \pm 0.3 \mathrm{mV}$ (mean \pm standard error) which is in the normal range for mice treated with non-myasthenic Ig, or for untreated control mice. ${ }^{5}$ 6 The mean MEPP-amplitude of the mouse treated with the myasthenic IgG fraction was markedly reduced $(0.37 \pm 0 \cdot 1 \mathrm{mV}$ and $0.32 \pm 0 \cdot 13$ $\mathrm{mV}$ respectively). Thus it was demonstrated that the myasthenic IgG fractions were impairing neuromuscular transmission on passive transfer (table).

\section{Localisation of $\lg G$}

All mice receiving treatment with myasthenic IgG displayed peroxidase stain at their motor endplates, indicating the presence of IgG (figs 1,2). In contrast no stained endplates were found in muscle from control animals. Motor endplate stain was also absent in the specificity control sections. Electron microscope studies (fig 3) revealed the stain predominantly at the tips of the postsynaptic folds, in good agreement with the distribution of the acetylcholine receptors. ${ }^{18}$
Some stain was also seen at the presynaptic membrane.

\section{Passive transfer of Fab and Fab $+I g G$}

The mean MEPP-amplitude in the diaphragms from two mice injected with the purified Fab fragments from two individual myasthenic patients were within the normal range $(0.51-$ $1.25 \mathrm{mV}$ for control mice (Toyka et al, ${ }^{5} 1977$, and unpublished observations) (table). At the end of the experimental period the Fab titre was measured in one of the mice and was found to be 0.64 pmol $\alpha$-Butx binding sites per $\mathrm{ml}$ as compared to $60 \mathrm{pmols}$ injected per day. Correspondingly only a weak precipitation line was seen when the mouse plasma was tested against anti-Fab serum on an Ouchterlony test. This indicates that the low $\mathrm{AB}$ titre was not merely due to inactivation of the receptor binding sites but rather to decreased circulating Fab concentration.

When $\mathrm{BDF}_{1}$ mice were treated with Fab fragments first and subsequently with Fab + IgG mean MEPP amplitudes were again not reduced (table). In these experiments the Fab concentration could not be measured because the anti-Fab serum cross-reacted with the IgG present in the mouse plasma. The determination of IgG levels revealed values that were closely comparable to the plasma concentrations in mice treated with IgG alone.

\section{Localisation of Fab at motor endplates}

Fab fragments were demonstrated at motor endplates in muscle cryosections of both mice treated with human myasthenic Fab (fig 4) by incubation with rabbit anti-Fab antibody followed by

Table Amplitudes of miniature endplate potentials (MEPP) and immunohistochemical localisation of IgC and Fab fragments at motor endplates in mice treated with human immunoglobulin (Ig) fractions

\begin{tabular}{|c|c|c|c|c|c|c|c|}
\hline Animal/strain & $\begin{array}{l}\text { No of } \\
\text { animals }\end{array}$ & Treatment & $\begin{array}{l}\text { Duration of } \\
\text { treatment }\end{array}$ & $\begin{array}{l}\text { Amount of } I g G \\
\text { or Fab+IgG } \\
(m g ! \text { day })\end{array}$ & $\begin{array}{l}\text { IgG/Fab " } \S \\
\text { present at motor } \\
\text { endplate }\end{array}$ & $\begin{array}{l}\text { Intensity of } \\
\text { endplate stain for } \\
\text { IgG/Fab } \S\end{array}$ & $\begin{array}{l}\text { MEPP amplitude } \\
(m V)\end{array}$ \\
\hline $\begin{array}{l}\text { Mouse/C57 } \\
\text {,, } \\
\text {,' } \\
\text { Mouse/B6D2F / J } \\
\text {,, } \\
\text {," } \\
\text {," }\end{array}$ & $\begin{array}{l}2 \\
2 \\
2 \\
2 \\
3 \dagger \\
2 \dagger \\
2 \\
1 \\
2\end{array}$ & $\begin{array}{l}\text { Myasthenic IgG } \\
\text { Control IgG } \\
\text { Myasthenic IgG } \\
\text { Control IgG } \\
\text { Myasthenic IgG } \\
\text { Control Ig } \\
\text { Myasthenic Fab§ } \\
\text { Control Fab } \\
\text { Myasthenic } \\
\text { Fab+IgG }\end{array}$ & $\begin{array}{l}3 \mathrm{~d} \\
3 \mathrm{~d} \\
30 \mathrm{~d} \\
30 \mathrm{~d} \\
10 \mathrm{~d} \\
10 \mathrm{~d} \\
9 \mathrm{~d} \\
7 \mathrm{~d} \\
9 \mathrm{~d}\end{array}$ & $\begin{array}{l}11-12 \\
11-12 \\
11-12 \\
11-12 \\
12 \\
12 \\
8 \\
8 \\
8+12 / 8+16\end{array}$ & $\begin{array}{l}\text { pos/n t } \\
\text { neg/n t } \\
\text { pos/n t } \\
\text { neg/n t } \\
\text { pos/n t } \\
\text { neg/n t } \\
\text { neg/pos } \\
\text { neg/neg } \\
\text { pos/pos }\end{array}$ & $\begin{array}{c}++1- \\
+1- \\
++1- \\
++1- \\
+1- \\
-1++ \\
+1- \\
++1++\end{array}$ & $\begin{array}{l}n t \\
n t \\
n t \\
n t \\
0 \cdot 37 / 0 \cdot 32 \\
0 \cdot 70^{*} \\
0 \cdot 80 / 0 \cdot 95 \\
(0 \cdot 69) \ddagger \\
0 \cdot 80 / 1 \cdot 14\end{array}$ \\
\hline
\end{tabular}

$\mathbf{n} \mathbf{t}=$ not tested.

* = mean MEPP amplitude for mice injected with control Ig $0.71 \mathrm{mV}(\mathrm{n}=10)$ and for myasthenic Ig $0.38 \mathrm{mV}(\mathrm{n}=13)^{5}$.

$+=3$ of these 5 mice were studied with MEPP measurements and 2 with immunohistochemistry on the following day.

$\ddagger \quad=$ only 10 fibres were analysed.

$\S=$ Ig from 2 individual myasthenic IgG fractions.

= staining for IgG with prot A-HRPO and for Fab with anti-Fab-IgG and then prot A-HRPO. 


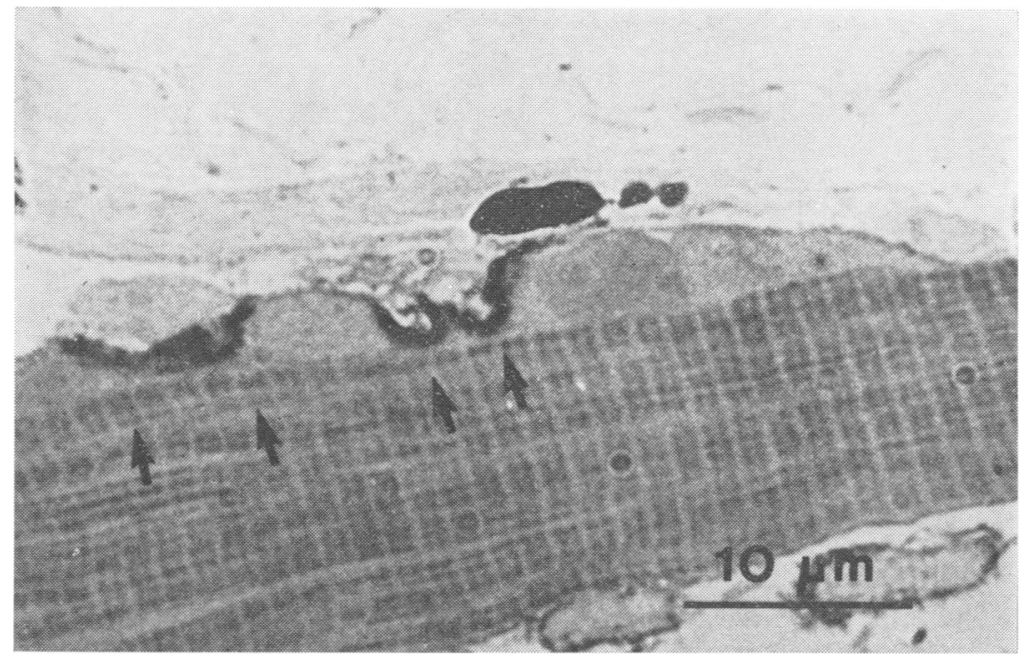

Fig $1 \quad 1.5 \mu m$ thick

Epon-section of a muscle fibre from a mouse treated with myasthenic $\mathrm{Ig} G$ for 3 days. Nerve terminals stained heavily for peroxidase activity (arrows). $A$ stained erythrocyte can be seen above the endplate $(\times 2500)$.

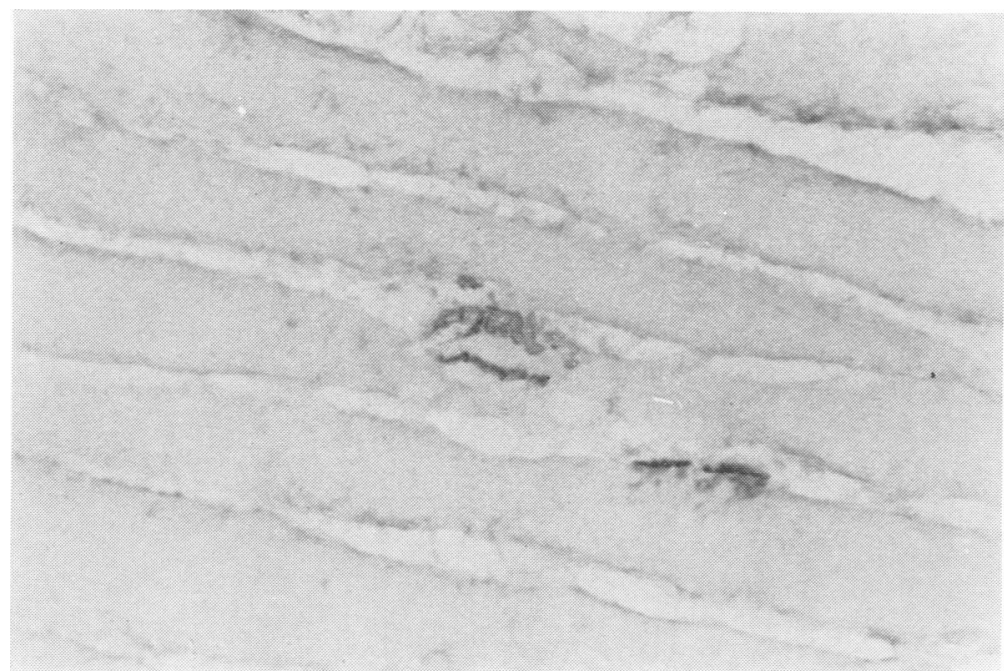

Fig 2 Photograph of cryosection demonstrating the localisation of $\lg G$ at motor endplates of a mouse treated with myasthenic $\operatorname{IgG}$ for 10 days $(\times 710)$.

prot A-HRPO. Sections from the same animals incubated with only prot A-HRPO were negative. Of the three different dilutions of anti-Fab antibody tested, $50 \mu / \mathrm{ml}$ was used since the higher concentrations produced excessive background stain. The stain produced at endplates of Fabtreated mice was less intense than the stain at endplates of mice treated with IgG. Fab could not be demonstrated at motor endplates of the one mouse receiving control Fab.

\section{Discussion}

The results obtained in this study suggest that treatment with monovalent Fab fragments obtained from myasthenic IgG protect the neuro- muscular junction from the effect of the native IgG antibody on MEPP amplitudes. Passive transfer of Fab fragments alone was ineffective in bringing about the neuromuscular transmission defect that was found in mice after transfer of IgG from the same patients. In previous investigations it was established that reduced MEPP amplitudes are a sensitive and valid parameter for assessment of the transmission defect in MG and its animal models. ${ }^{\text {19-21 4-5 }}$

The presence of Fab fragments and IgG was clearly demonstrated by specific immunohistochemical staining at the neuromuscular junction of animals injected with myasthenic immunoglobulin fractions, but not in control animals.

No major ultrastructural changes were observed 


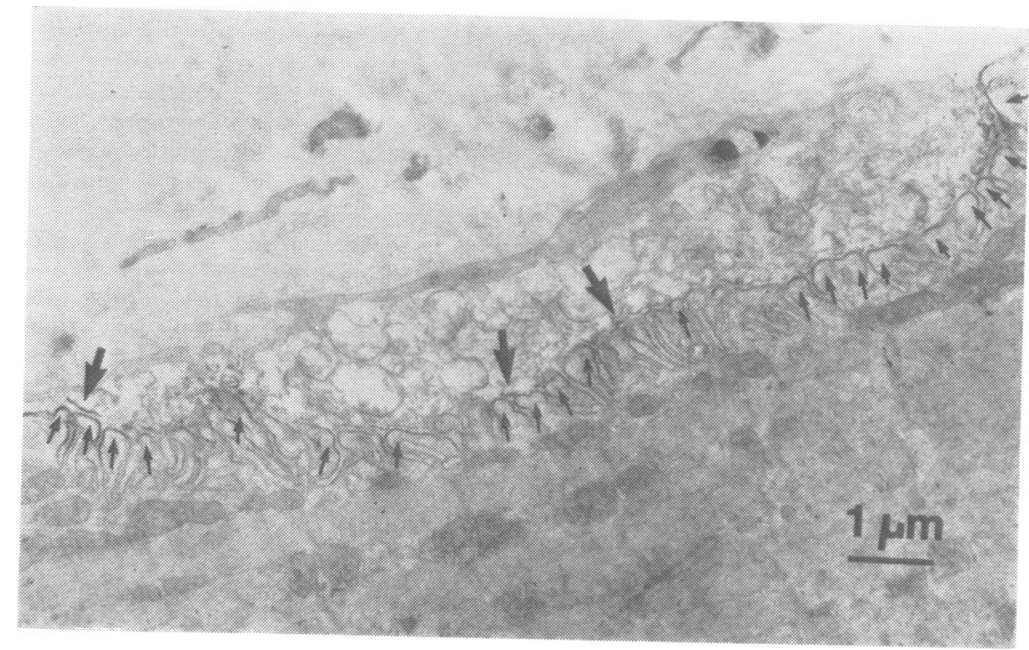

Fig 3 Electron micrograph of motor endplate from a mouse treated with myasthenic $\mathrm{IgG}$ for 30 days. Stain predominantly at the tips of the postsynaptic folds (thin arrows) which appear structurally normal. Some stain also visible at the presynaptic membrane. Regular counterstaining has been omitted to avoid obscuring peroxidase stain.

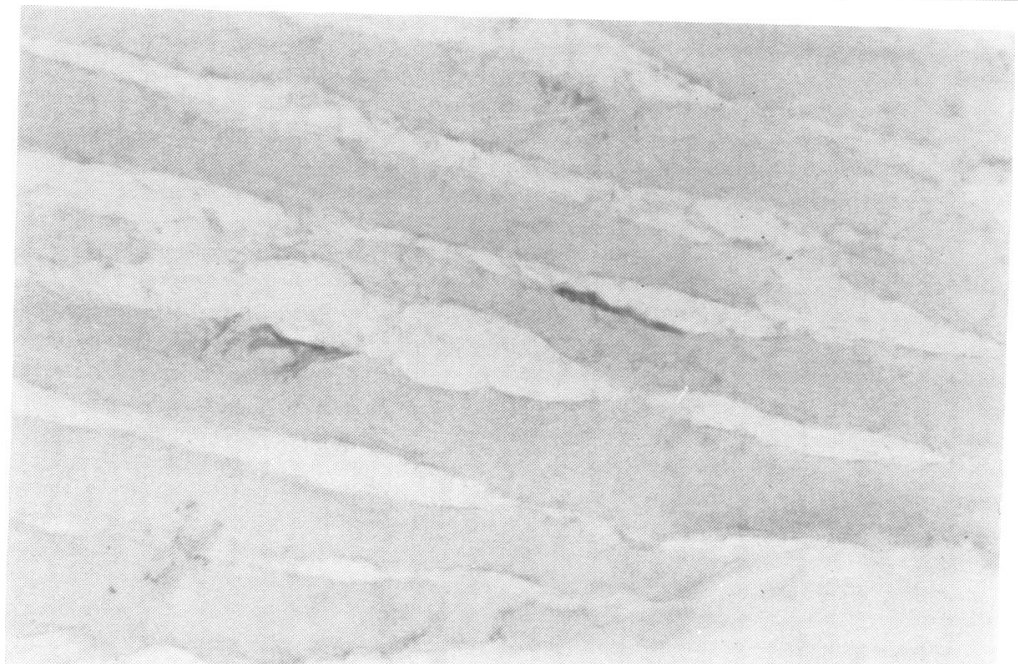

Fig 4 Photograph of cryosection demonstrating the localisation of Fab at motor endplates of a mouse treated with myasthenic Fab $(\times 710)$.

at motor endplates of mice exposed to MG-IgG for 30 days. The experiment was, however, designed for ultrastructural localisation of $\mathrm{IgG}$, therefore the tissue-preservation was probably not good enough to allow minor alterations of motor endplate structure to be discerned. Similar findings of unchanged morphology were reported in a preliminary study in 8 to 10 day experiments. ${ }^{6}$ This is at variance with observations in human MG where widening of synaptic folds and a reduction of the postsynaptic surface area were reported. ${ }^{22} \mathrm{~A}$ complement mediated lesion of the postsynaptic membranes is likely to be the basic mechanism for these morphological alterations, since IgG and complement components ( $\mathrm{C} 3$ and $\mathrm{C} 9$ ) were identified in the synaptic cleft. ${ }^{23}$ The role of complement has further been documented by passive transfer of chronic EAMG to syngeneic recipients. After deprivation of the third component of complement no clinical weakness ensued in these animals. ${ }^{24}$ In the mouse transfer model the lack of endplate damage even after 30 days of transfer may be due to incomplete complement activation across the species barrier as has been suggested by findings in earlier experiments. ${ }^{\circ}$

There are two possible explanations why Fab fragments did not impair neuromuscular transmission. The monovalent Fab fragment is unable to activate complement ${ }^{25}$ and to cross-link receptor binding sites. ${ }^{8}$ Using muscle cell cultures it has been demonstrated that intact IgG antibodies from myasthenic serum accelerate the process of AChR degradation ${ }^{26-27}$ while Fab 
fragments were inactive. ${ }^{8}$ In the latter study, after cross-linking $\mathrm{Fab}$ by a second antibody (anti-Fab) an increased rate of degradation was again observed. These experiments were performed in the absence of complement.

In a recent biochemical study Fab fragments from rabbits with experimental autoimmune MG were found to bind to AChR from Torpedo californica ard to inhibit further binding of the IgG fraction of identical sera. ${ }^{28}$

The staining of endplates from mice after passive transfer of $\mathrm{Fab}$ fragments was less intense than that observed after IgG from myasthenic sera. Furthermore, the concentration of circulating Fab was found to be less than one twentieth of the corresponding levels in IgGtreated animals, although equivalent amounts of antigen-binding sites were injected per day. This is in agreement with the observation that heterogeneous Fab fragments are rapidly distributed and eliminated by the kidney. ${ }^{29}$ This in turn leads to a shorter plasma halflife of Fab than is seen after passive transfer of IgG in rabbits and baboons. ${ }^{30}$ Therefore the possibility cannot be excluded that the available number of antigen-binding sites carried by Fab fragments in our experiments was too low to reduce MEPP amplitudes.

If the amount of Fab fragments combining with receptor sites was indeed much lower than corresponding IgG concentrations, then it is surprising that pre-treatment with Fab protected the neuromuscular junction against IgG. We suggest that Fab fragments acted by interfering with the binding of IgG and by effectively blocking the cross-linking of IgG with AChR binding sites. If cross-linking were the crucial first step in antibody-receptor interaction only a portion of the receptor binding sites has to be blocked by a ligand in order to inhibit the antibody effect. The hypothesis has been proposed that a network of antibody molecules connects adjacent AChR binding sites ultimately allowing the activation of complement. ${ }^{31}$ Blocking of only a small portion of binding sites by Fab might then prevent the myasthenic transmission defect. We conclude that Fab fragments may protect the receptor from antibody attack at low concentrations. It is not known whether Fab fragments could also show this effect after binding of antibody to AChR has occurred. In this case treatment with homologous Fab fragments might provide a mode of specific experimental immunotherapy.

This work was partly supported by a grant from the Deutsche Forschungsgemeinschaft to KVT and UAB (To 61/3), and by a grant from the Swedish Medical Research Council No B80-13X03907-08A. We thank Sheila J Brinkmann for reviewing the English manuscript and for secretarial assistance.

\section{References}

1 Lennon VA. The immunopathology of myasthenia gravis. Hum Pathol 1978; 9:541-51.

2 Heilbronn E, Stalberg E. The pathogenesis of myasthenia gravis. $J$ Neurochem 1978; 31:5-11.

3 Drachman DB. Myasthenia gravis. N Engl J Med 1978; 298:136-42, 186-93.

4 Toyka KV, Drachman DB, Pestronk A, Kao I. Myasthenia gravis: passive transfer from man to mouse. Science 1975; 190:397-9.

5 Toyka KV, Drachman DB, Griffin DE et al. Myasthenia gravis: study of humoral immune mechanisms by passive transfer to mice. $N E n g l$ J Med 1977; 296:125-31.

6 Toyka KV, Birnberger KL, Anzil AP, Schlegel C, Besinger UA, Struppler A. Myasthenia gravis: further electrophysiological and ultrastructural analysis of the transmission failure in the mouse passive transfer model. J Neurol Neurosurg Psychiatry 1978; 41:746-53.

7 Stanley EF, Drachman DB. Effect of myasthenic immunoglobulin on acetylcholine receptors at intact neuromuscular junctions. Science 1978; 200:1285-7.

8 Drachman DB, Angus CW, Adams RN Michelson JD. Hoffman GJ. Myasthenic antibodies cross-link acetvlcholine receptors to accelerate degradation. $N$ Engl J Med 1978; 298: 1116-22.

9 Levfert AK, Bergström K, Matell G. Osterman PO, Pirskanen R. Determination of acetylcholinereceptor-antibody in myasthenia gravis: clinical usefulness and pathogenetic implications. $J$ Neurol Neurosurg Psychiatry 1978; 41:394-403.

10 Toyka KV. Becker T. Fateh-Moghadam A et al. Die Bedeutung der Bestimmung von Antikörpern gegen Acetylcholin-rezeptoren in der Diagnostik der Myasthenia gravis. Klin Wochensch 1979; 57:937-42.

11 Peterson EA. Cellulosic ion exchangers. In: Work TS, Work E. eds. Laboratory Techniaues in Binchemistrv and Molecular Biologv. Vol 2. Part II Amsterdam: North Holland Publishing Co. 1970

12 Edelman GM, Marchalonis JJ. Preparation of antigens and antibodies. In: Williams CA. Chase MW. eds. Methots in Immunology and Immunochemistry, Vol 1. New York: Academic Press. 1967.

13 Nagel W. Willig F. Peschke W. Schmidt FH. Über die Bestimmung von Trypsin und Chvmotrypsin mit Aminosäure-p-Nitroaniliden. Hoppe Seylers Z Physiol Chem 1965; 340:1-10.

14 Nakame PK, Kawoi A. Peroxidase-labelled antibody: a new method of conjugation. $J$ Histochem 
Cytochem 1974; 22:1084-91.

15 Engel AG, Lambert EH, Howard FM. Immune complexes (IgG and $\mathrm{C} 3$ ) at the motor end-plate in myasthenia gravis: ultrastructural and light microscopic localisation and electrophysiologic correlations. Mayo Clin Proc 1977; 52:267-80.

16 Karnovsky MJ. The ultrastructural basis of capillary permeability studied with peroxidase as a tracer. J Cell Biol 1967; 35:213-36.

17 Axelsen NH, Kröll J, Weeke B. Quantitative immuno - electrophoresis. Universitetsforlaget (Oslo) 1973; 162.

18 Fertuck HC, Salpeter MM. Localisation of acetylcholine receptor by ${ }^{125} \mathrm{I}$-labelled $\alpha$-bungarotoxin binding at mouse motor endplates. Proc Nat Acad Sci USA 1974; 71:1376-8.

19 Albuquerque EX, Rash JE, Mayer RF, Satterfield JR. An electrophysiological and morphological study of the neuromuscular junction in patients with myasthenia gravis. Exp Neurol 1976; 51:536-63.

20 Heilbronn E, Mattson C, Thornell LE et al. Experimental myasthenia in rabbits: biochemical, immunological, electrophysiological and morphological aspects. Ann NY Acad Sci 1976; 274: 337-53.

21 Lambert EH, Lindström JM, Lennon VA. Endplate potentials in experimental autoimmune myasthenia gravis in rats. Ann NY Acal Sci 1976; 274:300-18.

22 Engel AG, Santa T. Histometric analysis of the ultrastructure of the neuromuscular junction in myasthenia gravis and the myasthenic syndrome. Ann NY Acad Sci 1971; 183:46-63.

23 Engel AG, Sahashi K, Lambert EH, Howard FM. The ultrastructural localisation of the acetylcholine receptor, immunoglobulin $\mathbf{G}$ and the third and ninth complement components at the motor end-plate and their implications for the patho- genesis of myasthenia gravis. In: Aguayo AJ, Karpati G, eds. Current Topics in Nerve and Muscle Research. Amsterdam: Excerpta Medica, 1979.

24 Lennon VA, Seybold ME, Lindström JM, Cochraine C, Ulevitch R. Role of complement in the pathogenesis of experimental autoimmune myasthenia gravis. J Exp Med 1978; 146:973-83.

25 Ruddy S, Gigli I, Austen KF. The complement system in man. $N$ Engl J Med 1972; 287:489-95.

26 Kao I, Drachman DB. Myasthenic immunoglobulin accelerates acetylcholine receptor degradation. Science 1977; 196:527-9.

27 Appel SH, Anwyl R, McAdams MW, Elias S. Accelerated degradation of acetylcholine receptor from cultured rat myotubes with myasthenia gravis sera and globulins. Proc Nat Acad Sci USA 1977; 74:2130-4.

28 Mihovilovic M, Martinez-Carrion M. Purification of high-affinity Fab fragments from experimental autoimmune myasthenia gravis rabbits and their effect on isolated acetylcholine receptors. Biochemistry 1979; 18:4522-8.

29 Arend WP, Silverblatt FJ. Serum disappearance and catabolism of homologous immunoglobulin fragments in rats. Clin Exp Immunol 1975; 22: 502-13.

30 Smith TW, Lloyd BL, Spicer N, Haber E. Immunogenicity and kinetics of distribution and elimination of sheep digoxin-specific IgG and Fab fragments in the rabbit and baboon. Clin Exp Immunol 1979; 36:384-96.

31 Lindström JM. The role of antibodies to the acetylcholine receptor protein and its component peptides in experimental autoimmune myasthenia gravis. In: Dau PC, ed. Plasmapheresis and the Immunobiology of myasthenia gravis. Boston: Houghton Mifflin, 1979. 